\title{
Adsorption of ferric ions onto natural feldspar: kinetic modeling and adsorption isotherm
}

\author{
M. A. Al-Anber
}

Received: 5 September 2012/Revised: 27 August 2013/Accepted: 29 October 2013/Published online: 16 November 2013

(C) Islamic Azad University (IAU) 2013

\begin{abstract}
The removing of ferric ions $\left(\mathrm{Fe}^{3+}\right)$ from aqueous solution using natural feldspar (NF) has been studied in a batch operation mode. The factors affecting of the sorption equilibrium, such as contact time, initial concentration of the ferric ions $\left(\mathrm{Fe}^{3+}\right)$, feldspar dosage concentration and temperature, were investigated. The maximum removal is $93 \%$ (approx.) using low-level concentration of $\mathrm{Fe}^{3+}$ ions $\left(30 \mathrm{mg} \mathrm{L}^{-1}\right)$ and high dosage concentration $\left(40 \mathrm{~g} \mathrm{~L}^{-1}\right)$. The adsorption equilibrium is achieved during the first 90 min. Freundlich model has successfully analyzed the equilibrium of isotherms with $R^{2}=1$. The adsorption mechanism of aqueous ferric ion on NF follows Freundlich isotherm models $\left(R^{2}=0.997\right)$. The capacity $\left(K_{\mathrm{f}}\right)$ and intensity $(1 / n)$ of Freundlich adsorption are 1.70 and 0.621 , respectively. The results reveal that the adsorption mechanism of ferric ion on NF is chemisorptions, heterogeneous multilayer and spontaneous in nature $\left(\Delta G=-19.778 \mathrm{~kJ} \mathrm{~mol}^{-1}\right)$. Adsorption reaction kinetic models, such as pseudo-first order and pseudosecond order, and adsorption diffusion model, such as Weber-Morris intraparticle diffusion model, have been used to describe the adsorption rate and mechanism of the ferric ion onto NF surface. Adsorption of ferric ion on the NF has achieved Lagergren pseudo-second-order model $\left(R^{2}=1.0\right.$ approx.) more than Lagergren pseudo-first-order model. The kinetic parameters, rate constant and sorption capacities have been calculated. The new information in
\end{abstract}

\section{A. Al-Anber $(\bowtie)$}

Department of Chemical Science, Faculty of Science, Mu'tah University, P.O. Box 7, Al-Karak 61710, Jordan

e-mail: masachem@mutah.edu.jo

M. A. Al-Anber

Department of Environmental Health, Faculty of Public Health and Health Informatics, University of Hail, Hail, Saudi Arabia this study suggests that NF could be used as a novel filtering materials for removing ferric ions from water.

Keywords Ferric ion - Feldspar · Adsorption ·

Freundlich $\cdot$ Kinetic $\cdot$ Thermodynamic

\section{Introduction}

Jordan has adopted several approaches to meet the challenges of water shortages. One of these approaches is to increase water resources in terms of the establishment of dams and drilling of artesian wells. Unfortunately, the industry has become a real source of the contamination of these water resources with heavy metals, e.g., iron ions. The presence of iron ions more than health level $\left(<0.3 \mathrm{mg} \mathrm{L}^{-1}\right)$ may cause anorexia, oliguria and diphasic shock (Brezonik 1974). In addition, it can give a metallic taste and odor to water (Zamzow and Murphy 1992). Due to these problems, a special attention should be paid on the removing or decreasing iron ion contents from industrial water effluents.

Traditional and numerous techniques are presented for removing the dissolved heavy metals out of the water system, including ion exchange, precipitation, phytoextraction, ultra-filtration, reverse osmosis and electrodialysis (Appegate 1984; Sengupta and Clifford 1986; Geselbarcht 1996). Unfortunately, some of them are not economically feasible and good for removing the heavy metal ions at the trace level or high level. Therefore, adsorption onto natural solid adsorbent is reported to be the potential alternative technique to purify the aqueous system (Bernardo et al. 2008; Tinschert et al. 2000). Among these, adsorbents are activated carbon (Edwin Vasu 2008), chitin (Karthikeyan et al. 2005), chitosan (Burke et al. 2002 and Wan et al. 2005), egg shells (Yeddou and Bensmaili 2007), 
olive cakes (Al-Anber and Al-Anber 2008a), zeolite (AlAnber and Al-Anber 2008b), jojoba seeds (Al-Anber et al. 2011), quartz and bentonite (Al-Anber 2010). Based on the these recent works, natural feldspar (NF) is considered one of the natural inorganic materials that show remarkable potential toward removing of toxic heavy metals from aqueous solutions. For example, high atomic densities $\mathrm{Pb}$, $\mathrm{Ni}, \mathrm{Cd}, \mathrm{Cu}$ and $\mathrm{Zn}$ ions have been removed from aqueous solutions (Aşç1 et al. 2008; Fraga 2005; Liu et al. 2007; Wang et al. 2006; Pan and Lu 2008).

Natural feldspar (NF) exists in different parts of Jordan especially in the Aljeich region in southern part of Jordan. The feldspar is extracted from granite that located in the valleys. Feldspar is the most important single group of rock forming silicate minerals (Apodaca 2008, Wikipedia). There are four chemically district group of feldspar: potassium feldspar $\left(\mathrm{KAlSi}_{3} \mathrm{O}_{8}\right)$, sodium feldspar $\left(\mathrm{NaAlSi}_{3} \mathrm{O}_{8}\right)$, calcium feldspar $\left(\mathrm{CaAlSi}_{3} \mathrm{O}_{8}\right)$ and barium feldspar $\left(\mathrm{BaAlSi}_{3} \mathrm{O}_{8}\right)$ (Disediakan Oleh and Ariffin 2003). These kinds of feldspars are an important ingredient in the manufacturing of glass (Bernardo et al. 2008), fabrication of ceramics materials (Tinschert et al. 2000) and paint (Michael et al. 2006). The major constituents of NF surface are alumina and silica. A surface functional group of feldspar is a plane of oxygen atoms bound to the silica and hydroxyl groups that are associated with the silicate structural units (Awan et al. 2003; Donald 1998). These functional groups provide surface sites for the chemisorptions of metal ions (Murray 1994). The adsorption process via NF considers the potential alternative for removing $\mathrm{Fe}^{3+}$ ions especially for these countries of limiting resources. This is due to the several reasons, for example, it has easy handling, low cost, naturally occurring, huge quantity and safe for the environment.

Herein, feldspar surface can be used for removing highlevel concentration of $\mathrm{Fe}^{3+}$ ions from a model aqueous solution. The equilibrium distribution of ferric ion between the sorbent and the solution is important in determining the maximum sorbent capacity. The two isotherm models (Langmuir and Freundlich) will be used to assess the different isotherms and their ability to correlate experimental data. The Langmuir equation is chosen for the estimating the maximum adsorption capacity corresponding to complete monolayer coverage on the feldspar surface. The Freundlich model is chosen to estimate the adsorption intensity of the sorbent toward the feldspar.

\section{Materials and methods}

Natural feldspar (NF)

Natural feldspar as non-treated was supplied from the Directorate of Laboratories in the Natural Recourses
Authority of Jordan. NF was ground and then screened into a size fractions of $250 \mu \mathrm{m}$ using standard Tyler screen series. In order to remove carbonate and other impurities, chemical treatment was performed by adding three kinds of solution of $\mathrm{HCl}\left(0.1 \mathrm{moL} \mathrm{L}^{-1}\right), \mathrm{HNO}_{3}$ $\left(0.1 \mathrm{moL} \mathrm{L}^{-1}\right)$ and $\mathrm{NH}_{4} \mathrm{Cl}\left(0.1 \mathrm{moL} \mathrm{L}^{-1}\right)$ to the $\mathrm{NF}$ fractions, respectively. After $24 \mathrm{~h}$, the solid phases were separated from the solution. NF was then washed with excessive amounts of double de-ionized water until the filtrate gave a negative test for the chloride ion upon addition of several drops of $0.1 \mathrm{moL} \mathrm{L}^{-1} \mathrm{AgNO}_{3}$ solution to a sample from the filtrate. After the calcinations $\left(400-450{ }^{\circ} \mathrm{C}\right)$, NF fractions were stored in an oven at $110{ }^{\circ} \mathrm{C}$.

\section{Reagents}

All chemicals were used as received as analytical grade. $\mathrm{Fe}\left(\mathrm{NO}_{3}\right)_{3} \cdot 6 \mathrm{H}_{2} \mathrm{O}$ was purchased from Fluka $\mathrm{AG}$ (Buchs, Switzerland). $\mathrm{NaOH}\left(0.1 \mathrm{~mol} \mathrm{~L}^{-1}\right), \mathrm{HNO}_{3}\left(0.1 \mathrm{~mol} \mathrm{~L}^{-1}\right)$, $\mathrm{H}_{2} \mathrm{O}_{2}\left(0.1 \mathrm{~mol} \mathrm{~L}^{-1}\right)$ and $\mathrm{HCl}\left(0.1 \mathrm{~mol} \mathrm{~L}^{-1}\right)$ were purchased from Merck (Darmstadt, Germany). A stock solution of ferric ion ions was prepared by dissolving an exact amount of $\mathrm{Fe}\left(\mathrm{NO}_{3}\right)_{3} \cdot 6 \mathrm{H}_{2} \mathrm{O}( \pm 0.01 \mathrm{~g})$ in $990 \mathrm{~mL}$ ultrapure deionized water $(18 \Omega \mathrm{cm})$, and then, $10 \mathrm{~mL}$ of $\mathrm{HNO}_{3}$ must be added to complete the total volume of solution to $1,000 \mathrm{~mL}$. Standard ferric ion solutions of 30, 50, 100, 150 and $200 \mathrm{mg} \mathrm{L}^{-1}$ were prepared by appropriate dilution. An "initial" $\mathrm{pH}$ and its subsequent adjustment for all experimental runs were conducted $<1.20$ at the maximum value. The initial $\mathrm{pH}$ of the solution was adjusted using $1 \%$ $\mathrm{HNO}_{3}$ for all experiment runs.

\section{Apparatus and instruments}

The metal concentration in the solution was measured using the atomic absorption spectrophotometer, AAS (PerkinElmer Analyst 300). The chemical analysis of the feldspar was determined using X-ray fluorescence (XRF) analyzers (Desktop Elemental XRF Analyzer: EX-310). The mixtures were mixed by a thermostatic mechanical shaker at constant temperature $\left(20,30\right.$ and $40{ }^{\circ} \mathrm{C}$, Isothermal Gefellschaft Fur 978). To ensure accuracy in preparation, analytical balance is used (Sartorius, CP324-S/ management system certified according to ISO 9001).

\section{Equilibrium studies}

The uptake of ferric ion $\left(\mathrm{Fe}^{3+}\right)$ was calculated from the mass balance, which was stated as the amount of $\mathrm{Fe}^{3+}$ ions adsorbed onto the NF. It equal the amount of $\mathrm{Fe}^{3+}$ ions removed from the aqueous solution. Mathematically can be expressed in Eqs. 1-2: 
$q_{\mathrm{e}}=\frac{\left(C_{\mathrm{i}}-C_{\mathrm{e}}\right)}{S}$

$q_{\mathrm{t}}=\frac{\left(C_{\mathrm{i}}-C_{\mathrm{t}}\right)}{S}$

where $q_{\mathrm{e}} \mathrm{Fe}^{3+}$ ions amount adsorbed on NF surface at equilibrium $\left(\mathrm{mg} \mathrm{g}^{-1}\right) \cdot q_{\mathrm{t}} \mathrm{Fe}^{3+}$ ions amount adsorbed on $\mathrm{NF}$ surface at a specific time $\left(\mathrm{mg} \mathrm{g}^{-1}\right) . C_{\mathrm{i}}$ Initial concentration of $\mathrm{Fe}^{3+}$ ions in the aqueous solution $\left(\mathrm{mg} \mathrm{L}^{-1}\right) . C_{\mathrm{e}}$ Equilibrium concentration or final concentration of $\mathrm{Fe}^{3+}$ ions in the aqueous solution $\left(\mathrm{mg} \mathrm{L}^{-1}\right) . C_{\mathrm{t}}$ The final concentration of $\mathrm{Fe}^{3+}$ ions in the aqueous solution $\left(\mathrm{mg} \mathrm{L}^{-1}\right)$ at a specific time. $S$ Dosage (slurry) concentration of NF and it is expressed by:

$S=\frac{m}{v}$

where $v$ is the initial volume of $\mathrm{Fe}^{3+}$ ions solution used (L) and $m$ is the mass of NF adsorbent.

The percent adsorption (\%) was also calculated using the following equations

$\%$ adsorption $=\frac{C_{\mathrm{i}}-C_{\mathrm{e}}}{C_{\mathrm{i}}} \times 100 \%$

Effect of the initial concentration

Adsorption measurements were made by a batch technique at temperature of $30\left( \pm 1{ }^{\circ} \mathrm{C}\right)$. The stopper plastic flasks containing $50 \mathrm{~mL}$ of different initial concentrations $\left(C_{\mathrm{i}}=30,50,100,150\right.$ and $\left.200 \mathrm{mg} \mathrm{L}^{-1}\right)$ of $\mathrm{Fe}^{3+}$ ions and $10 \mathrm{~g} \mathrm{~L}^{-1}$ of $\mathrm{NF}$ were shaken vigorously using thermostatic mechanical shaker for $3.0 \mathrm{~h}$. The agitation speed $(300 \mathrm{rpm})$ was kept constant for each run to ensure equal mixing. At the end of the equilibrium time, the flasks were removed from the shaker and then the solution was filtered using filter paper (Whatman No. 41). The filtrate samples were analyzed. All the reported results were the average of at least triplicate measurements.

\section{Effect of the temperature}

The adsorption experiments were carried out by shaking vigorously the stopper plastic flasks containing $50 \mathrm{~mL}$ of $100 \mathrm{mg} \mathrm{L}^{-1}$ of ferric ions solution (initial $\mathrm{pH}=1.15$ ) and $10 \mathrm{~g} \mathrm{~L}^{-1}$ of NF using thermostatic mechanical shaker at constant contact time $(3 \mathrm{~h})$ and agitation speed $(300 \mathrm{rpm})$ with variant temperatures $\left(30,40\right.$ and $\left.50{ }^{\circ} \mathrm{C}\right)$. At the end of the equilibrium time, the flasks were removed from the shaker and then the solution was filtered using filter paper (Whatman No. 41). The filtrate samples were analyzed. All the reported results were the average of at least triplicate measurements.
Effect of dosage

Adsorption measurements were made by a batch technique at temperature of $30\left( \pm 1^{\circ} \mathrm{C}\right)$. Different doses of $\mathrm{NF}(2,6$, $10,20,30$ and $40 \mathrm{~g} \mathrm{~L}^{-1}$ ) were placed in a $100-\mathrm{mL}$ stopper plastic flask containing $50 \mathrm{~mL}$ of $100 \mathrm{mg} \mathrm{L}^{-1}$ of ferric ions solution (initial $\mathrm{pH}=1.15$ ). The solutions were shaken vigorously (agitation speed $=300 \mathrm{rpm}$ ) using thermostatic mechanical shaker for $3.0 \mathrm{~h}$. At the end of the equilibrium, the flasks were removed from the shaker and then solution was filtered using filter paper (Whatman No. 41). The filtrate samples were analyzed. All the reported results were the average of at least triplicate measurements.

\section{Effect of particle size}

Adsorption measurements were made by a batch technique at temperature of $30\left( \pm 1{ }^{\circ} \mathrm{C}\right)$. The temperature was fixed by a thermostatic mechanical shaker. Different particle sizes (45, 125 and $250 \mu \mathrm{m}$ ) of NF were placed in a 100-ml stopper plastic flask containing $50 \mathrm{~mL}$ of $100 \mathrm{mg} \mathrm{L}^{-1}$ of ferric ions solution (initial $\mathrm{pH}=1.15$ ). The solutions were shaken vigorously (agitation speed $=300 \mathrm{rpm}$ ) using thermostatic mechanical shaker for $180 \mathrm{~min}$. At the end of the equilibrium time, the flasks were removed from the shaker and the NF was then filtered using filter paper (Whatman No. 41). The filtrate samples were analyzed. All the reported results were the average of at least triplicate measurements.

\section{Effect of contact time}

The adsorption experiments were carried out by shaking $0.5 \mathrm{~g}$ of the NF with $50 \mathrm{~mL}$ of $100 \mathrm{mg} \mathrm{L}^{-1}$ of ferric ions solution (initial $\mathrm{pH}=1.15$, dosage $=10 \mathrm{~g} \mathrm{~L}^{-1}$ ). The solutions were shaken vigorously using thermostatic mechanical shaker at constant temperature $\left(30{ }^{\circ} \mathrm{C}\right)$ and dosage $\left(10 \mathrm{~g} \mathrm{~L}^{-1}\right)$. The agitation speed was fixed at $300 \mathrm{rpm}$ for a known period in the interval of 5-180 $\mathrm{min}$ with increment of $10 \mathrm{~min}$ from 10 to $60 \mathrm{~min}$ and then $30 \mathrm{~min}$ from 60 to $180 \mathrm{~min}$. At the end of the predetermined time, the filtrate samples were analyzed. All the reported results were the average of at least triplicate measurements.

\section{Results and discussion}

$\mathrm{X}$-ray fluorescence (XRF) analysis

X-ray fluorescence (XRF) analysis was carried out on the crude NF to determine its chemical compositions. Table 1 shows the chemical composition of NF. It can be seen that $\mathrm{SiO}_{2}$ and $\mathrm{Al}_{2} \mathrm{O}_{3}$ are two major components of NF. X-ray 
Table 1 Chemical composition of the natural feldspar (NF)

\begin{tabular}{lcr}
\hline Parameter & Unit & Results \\
\hline $\mathrm{CaO}$ & $\%$ & 0.05 \\
$\mathrm{SiO}_{2}$ & $\%$ & 67.05 \\
$\mathrm{MgO}$ & $\%$ & 0.13 \\
$\mathrm{Fe}_{2} \mathrm{O}_{3}$ & $\%$ & 0.04 \\
$\mathrm{Al}_{2} \mathrm{O}_{3}$ & $\%$ & 17.62 \\
$\mathrm{TiO}_{2}$ & $\%$ & 0.01 \\
$\mathrm{Na}_{2} \mathrm{O}$ & $\%$ & 2.51 \\
$\mathrm{~K}_{2} \mathrm{O}$ & $\%$ & 13.06 \\
$\mathrm{MnO}$ & $\%$ & 0.01 \\
\hline
\end{tabular}

diffraction analysis indicated that the NF is rich in orthoclase, plagioclase, quartz and microcline. It was found that the chemical group of feldspar is a mixture of potassium feldspar $\left(\mathrm{KAlSi}_{3} \mathrm{O}_{8}\right)$ and sodium feldspar $\left(\mathrm{NaAlSi}_{3} \mathrm{O}_{8}\right)$ and trace calcium feldspar $\left(\mathrm{CaAlSi}_{3} \mathrm{O}_{8}\right)$. Other metal oxides are present in traces or small amounts. These results are found agree with the Natural Resources Authority of Jordan (Natural 2006).

Calcinations did not lose the original silica. It was used due to the decomposition of last concentrations of carbonates and organic matter as well as dehydration of the structural and adsorbed water. The removing of original soluble metals in the NF can be tested using EDTA. The test was performed by adding several drops of $1.00 \times 10^{-3} \mathrm{~mol} \mathrm{~L}^{-1}$ EDTA solution $(\mathrm{pH}=10)$ and $2 \mathrm{ml}$ of $\mathrm{NH}_{3} / \mathrm{NH}_{4} \mathrm{Cl}$ buffer to an approximately $5 \mathrm{ml}$ sample from the filtrate. A suitable volume of Eriochrome black T is added to solution as indicator. The negative test for the presence of metal ions is indicated by appearing the blue color of solution. NF was then washed with excessive amounts of double-distilled water until the filtrate gave a negative test for chloride ion upon addition of several drops of $0.1 \mathrm{moL} \mathrm{L}^{-1} \mathrm{AgNO}_{3}$ solution to a sample from the filtrate.

The sorption of $\mathrm{Fe}^{3+}$ ions over NF could be performed through the suggested chemisorptions mechanistic through the binding of $\mathrm{Fe}^{3+}$ ion with the functional group of feldspar. The $\mathrm{Fe}^{3+}-\mathrm{NF}$ adsorption system has achieved Lagergren pseudo-second-order model $\left(R^{2}=1.0\right)$. This can support the suggestion of chemisorptions mechanistic between ferric ion and NF as reported in "Kinetic Modeling of $\mathrm{Fe}^{3+}$ Sorption" section of this study (Ho 2004). Based on this suggested sorption mechanism, the effect of contact time, dosage, initial concentration and temperatures was considered in our explanations.

\section{Effect of $\mathrm{Fe}^{3+}$ ions Concentration}

The water resources in Jordan contain varying proportions of iron ions, starting from low level to high. For this, we have used $30,50,100,150$ and $200 \mathrm{mg} \mathrm{L}^{-1}$ to achieve the current and future requirements. Figure 1 shows the removal percentage of $\mathrm{Fe}^{3+}$ ions using $\mathrm{NF}$ under the influence of these initial concentrations $(30,50,100,150$ and $200 \mathrm{mg} \mathrm{L}^{-1}$ ). The removal percentage decreases with increasing the initial concentration of $\mathrm{Fe}^{3+}$ ions. For example, the removal percentage was $93 \%$ using low-level concentration $\left(30 \mathrm{mg} \mathrm{L}^{-1}\right)$, while it was $81 \%$ using high level $\left(200 \mathrm{mg} \mathrm{L}^{-1}\right)$. At high-level concentrations, the available sites of adsorption become fewer. This behavior is connected with the competitive diffusion process of ferric ions onto NF surface. The presence of high ferric ion amount lead to plugging the inlet pores of NF surface, and this prevents ferric ion to pass deeply inside. This could decrease the total surface area and an increase in diffusion path length. This could contribute in decreasing the adsorbed amount per unit mass (AL-Ghezawi et al. 2010; Bhattacharyya and Gupta 2006; Yu et al. 2000). These results indicate that energetically less favorable sites by increasing metal concentration in aqueous solution. This result compatible with the recent studies, for example natural olive cake (Al-Anber and Al-Anber 2008a), zeolite (Al-Anber and Al-Anber 2008b), bentonite and quartz (AlAnber 2010) in addition to other reported example by Lakshminarayanan Rao et al. (1994) and Karthikeyan et al. (2005).

\section{Effect of temperature}

The adsorption mechanism can be detected by studying the temperature effect factor (Al-Anber 2011). The adsorption mechanism is often an important indicator to describe the type and the level of interactions between the $\mathrm{Fe}^{3+}$ ions

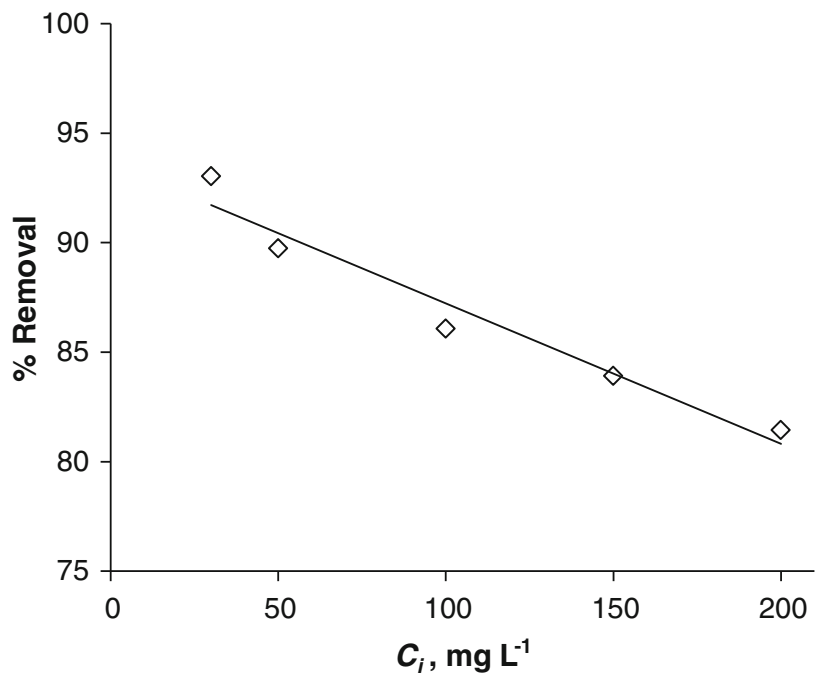

Fig. 1 The effect of initial concentration of $\mathrm{Fe}^{3+}$ ions namely 30, 50, 100,150 and $200 \mathrm{mg} \mathrm{L}^{-1}, 180 \mathrm{~min}, 10 \mathrm{~g} \mathrm{~L}^{-1}$ dosage of $\mathrm{NF}, 30{ }^{\circ} \mathrm{C}$ and $300 \mathrm{rpm}$ 
and NF adsorbent. The influence of temperature on the removal of $\mathrm{Fe}^{3+}$ ions from the aqueous solution has been studied through the applied of a variety of temperatures between the ranges of $30-50{ }^{\circ} \mathrm{C}$ (see Fig. 2). The chemisorptions of $\mathrm{Fe}^{3+}$ ions on NF surface has been found nonhighly affected by raising the value of temperatures. The maximum removal percentage was $90 \%$ and achieved at $50{ }^{\circ} \mathrm{C}$, while the lowest percentage was $87 \%$ at a temperature of $30{ }^{\circ} \mathrm{C}$. This indicates to the weakly chemical interaction of $\mathrm{Fe}^{3+}$ ions with NF surface (chemisorptions) (Mouflih et al. 2006). This type of interaction is typical to the adsorption of the aqueous $\mathrm{Co}^{2+}$ ions on the natural Tripoli (NT) (AL-Ghezawi et al. 2010).

\section{Dosage effects}

The removal percentage of $\mathrm{Fe}^{3+}$ ions from $100 \mathrm{mg} \mathrm{L}^{-1}$ aqueous solution using different dosages of $\mathrm{NF}(2,6,10$, 20, 30 and $40 \mathrm{~g} \mathrm{~L}^{-1}$ ) has been described in the Fig. 3. The removal percentage increases sharply as the adsorbent dose increases. This is due to the reason for increasing the number of the adsorption site in the NF adsorbent (Siddique et al. 1999). The maximum removal (93\% approx.) has been observed using the dosage of $40 \mathrm{~g} \mathrm{~L}^{-1}$.

\section{Effect of particle size}

Figure 4 represents the removal percentage of $\mathrm{Fe}^{3+}$ ions from $100 \mathrm{mg} \mathrm{L}^{-1}$ aqueous solution using different particle sizes of NF (45, 125 and $250 \mu \mathrm{m})$. The maximum removal percentage is achieved with particle size $45 \mu \mathrm{m}(88 \%)$. The smaller particle size is found to be more efficient than the larger size; this is attributed to the increasing availability and accessibility of the adsorption surface. Availability is related to the equilibrium behavior of the adsorption system (available functional group is the one

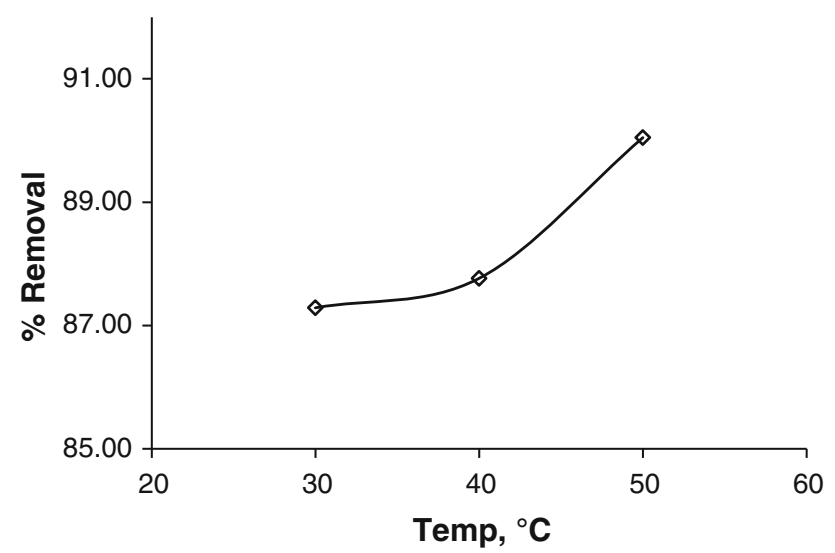

Fig. 2 The influence of temperature on the removal of $\mathrm{Fe}^{3+}$ ions from the $100 \mathrm{mg} \mathrm{L}^{-1}$ of aqueous $\mathrm{Fe}^{3+}$ ions solution through the following parameters: $3 \mathrm{~h}, 10 \mathrm{~g} \mathrm{~L}^{-1} \mathrm{NF}$ dosage and $300 \mathrm{rpm}$ that can be reacted with the ferric ion). Accessibility is related to the kinetic behavior of the ferric ion adsorption system. It expresses the ease of reacting and adsorbing ferric ion onto the surface functional group of NF.

Adsorption isotherm

The equilibrium distribution of $\mathrm{Fe}^{3+}$ ions between the NF and the solution is important in determining the maximum sorption capacity. Several isotherm models are available to describe the equilibrium sorption distribution. Two models are used to fit the experimental data: Langmuir and Freundlich models (Domenico and Schwartz 1990; Reddi and Inyang 2000; Nitzsche and Vereecken 2002; Zeldowitsch

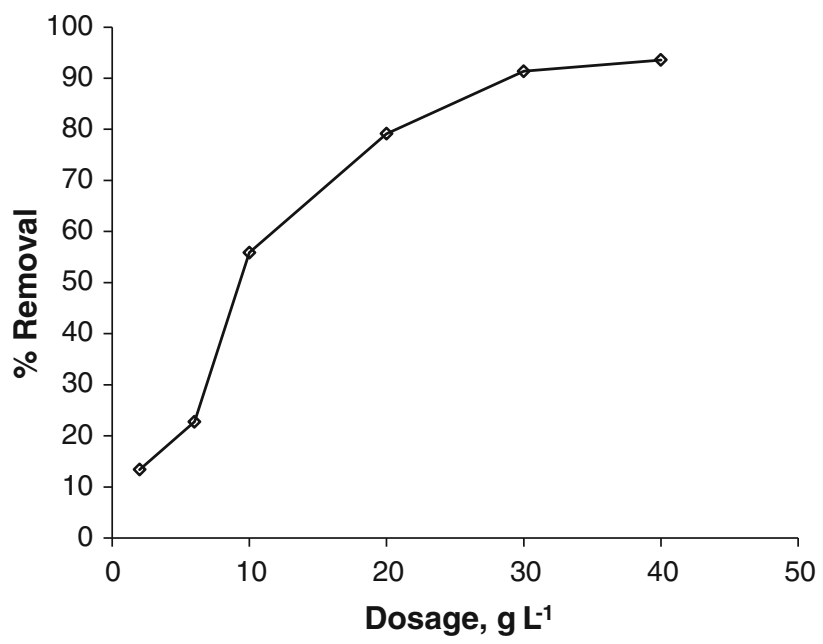

Fig. 3 The effect of NF adsorbent dosage (2, 6, 10, 20, 30 and $40 \mathrm{~g} \mathrm{~L}^{-1}$ ) on the removal $\mathrm{Fe}^{3+}$ ions from the $100 \mathrm{mg} \mathrm{L}^{-1}$ aqueous solution at $3 \mathrm{~h}, 30^{\circ} \mathrm{C}$ and $300 \mathrm{rpm}$

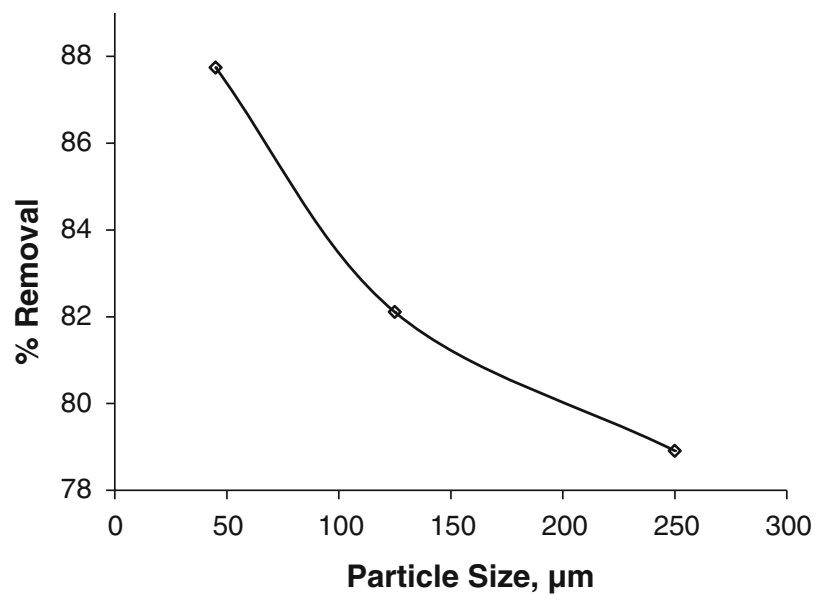

Fig. 4 The removal percentage of $\mathrm{Fe}^{3+}$ ions from $100 \mathrm{mg} \mathrm{L}^{-1}$ aqueous solution using different particle sizes of NF (45, 125 and $250 \mu \mathrm{m})$ 
1934; Naushad et al. 2013). Isotherm studies were conducted at $30{ }^{\circ} \mathrm{C}$ by varying the initial concentration of $\mathrm{Fe}^{3+}$ ions. Representative initial concentration $(30,50,100,150$ and $200 \mathrm{mg} \mathrm{L}^{-1}$ ) of $\mathrm{Fe}^{3+}$ ions were mixed with slurry concentrations (dose) of $10 \mathrm{~g} \mathrm{~L}^{-1}$ for $180 \mathrm{~min}$, which was the equilibrium time for the $\mathrm{NF}$ and $\mathrm{Fe}^{3+}$ chemisorptions mixture.

The linear form of Langmuir model is given by

$\frac{C_{\mathrm{e}}}{q_{\mathrm{e}}}=\frac{1}{q_{\max } b}+\frac{1}{q_{\max }} C_{\mathrm{e}}$

where $q_{\mathrm{e}}: \mathrm{Fe}^{3+}$ ions amount $(\mathrm{mg})$ on the NF (g) at equilibrium $\left(\mathrm{mg} \mathrm{g}^{-1}\right)$; and $q_{\max }$ is the maximum metal ions uptake per unit dosage of adsorbent $\left(\mathrm{mg} \mathrm{g}^{-1}\right)$, which is related to adsorption capacity and $\mathrm{b}$ is Langmuir constant $\left(\mathrm{L} \mathrm{g}^{-1}\right)$ which is exponentially proportional to the heat of adsorption as well as it related to the affinity of binding sites and is a measure of energy of adsorption. Therefore, a plot of $\mathrm{C}_{\mathrm{e}} / \mathrm{q}_{\mathrm{e}}$ versus $C_{e}$ gives a straight line of slope $1 / q_{\max }$ and intercept $1 /\left(\mathrm{q}_{\max } \mathrm{b}\right)$. The thermodynamic and the equilibrium results were obtained at the $1 \% \mathrm{HNO}_{3}$ model solution of $\mathrm{Fe}^{3+}$ ions, which are summarized in the Table 2.

The Langmuir isotherm model is applied to the experimental data giving a correlation regression coefficient $\left(R^{2}=0.936\right)$, which is a measure of goodness-of-fit and the general empirical formula of the Langmuir model by $\frac{c_{\mathrm{e}}}{q_{\mathrm{e}}}=0.040 c_{\mathrm{e}}+0.867$. Our results are in a good qualitatively agreements with those found from adsorption of $\mathrm{Fe}^{3+}$ on the palm fruit bunch and maize cob (Nassar et al. 2004).

On the other side, Freundlich model is commonly used to describe the adsorption characteristics for the heterogeneous surface. It represents an initial surface adsorption followed by a condensation effect resulting from strong adsorbate-adsorbate interaction.

The linear form of Freundlich model is also given by

$\ln q_{\mathrm{e}}=\ln K_{\mathrm{F}}+\left(\frac{1}{\mathrm{n}}\right) \ln c_{\mathrm{e}}$

where $K_{\mathrm{F}}$ and $\mathrm{n}$ are Freundlich constants determined from the slope and intercept of plotting $\ln q_{\mathrm{e}}$ versus $\ln c_{\mathrm{e}}$.

Figure 5 represents the fitting experimental data into the Freundlich model. The empirical formula of this model is found as $\ln q_{\mathrm{e}}=0.622 \ln c_{\mathrm{e}}+0.531$ with $R^{2}$ value equals to 0.997 . The Freundlich model has a better fitting model than Langmuir; as the former have higher correlation regression coefficient than the latter. Furthermore, we have found that the experimental isotherm, as shown in Fig. 6 with $R^{2}=0.998$, is largely identical with the Freundlich isotherm model. The smaller value of the heterogeneity parameter $(1 / \mathrm{n})$ means the greater the expected heterogeneity (Kinniburgh 1985; Kinniburgh 1986; Kannan and Meenakshisundaram 2002). The results exhibit a value of $1 / \mathrm{n}(0<(1 / \mathrm{n})<1)$ indicating the more heterogeneous chemisorptions of $\mathrm{Fe}^{3+}$ ions over the surface of NF (AlAnber 2011).

The effect of isotherm shape is discussed from the direction of predicting the weather, and adsorption system is "favorable" or "unfavorable." It was previously reported (Al-Anber 2011) that the dimensional analysis, separation factor or equilibrium parameters " $\mathrm{R}_{\mathrm{L}}$ " were as an essential feature of the Langmuir isotherm to predict adsorption system to be "favorable" or "unfavorable" by Eq. 7:

$\mathrm{R}_{\mathrm{L}}=1 /\left(1+\mathrm{bC}_{\mathrm{i}}\right)$

Table 2 List the compression of the parameters of the adsorption isotherm of ferric ion onto various Jordanian natural adsorbents and others

\begin{tabular}{|c|c|c|c|c|c|c|c|c|}
\hline & \multicolumn{4}{|l|}{ Langmuir } & \multicolumn{3}{|c|}{ Freundlich } & \multirow[t]{2}{*}{ References } \\
\hline & $q_{\max }\left(\mathrm{mg} \mathrm{g}^{-1}\right)$ & $b\left(\mathrm{~L} \mathrm{mg}^{-1}\right)$ & $\Delta G$ & $R^{2}$ & $\overline{K_{\mathrm{f}}}$ & $1 / n$ & $R^{2}$ & \\
\hline \multicolumn{9}{|l|}{ Jordanian adsorbents } \\
\hline Natural bentonite (NB) & 20.96 & 0.005 & -13.90 & 0.938 & 0.202 & 0.775 & 0.992 & (Al-Anber 2010) \\
\hline Natural quartz (NQ) & 14.49 & 0.004 & -13.40 & 0.961 & 0.115 & 0.780 & 0.996 & (Al-Anber 2010) \\
\hline Olive cake (OC) & 58.48 & 0.015 & -16.87 & 0.96 & 2.164 & 0.628 & 0.992 & (Al-Anber and Al-Anber 2008a) \\
\hline Natural zeolite (NZ) & 7.35 & 0.014 & -16.98 & 0.998 & 3.353 & 0.106 & 0.954 & (Al-Anber and Al-Anber 2008b) \\
\hline Feldspar (NF) & 25.00 & 0.046 & -19.78 & 0.94 & 1.70 & 0.621 & 0.997 & This study \\
\hline \multicolumn{9}{|l|}{ Others } \\
\hline Carbon & 6.14 & 0.274 & & 1.00 & & & & (Edwin 2008) \\
\hline Eggshells & 5.991 & 1.285 & & 0.983 & 3.0 & 0.608 & 0.959 & (Yeddou and Bensmaili 2007) \\
\hline Chitosan & 90.09 & 2.413 & & 0.999 & 55.27 & 0.301 & 0.982 & (Burke et al. 2002 and Wan et al. 2005) \\
\hline Chitin & 1.3982 & 0.2591 & -4.52 & 0.975 & 2.45 & 0.67 & 0.995 & (Karthikeyan et al. 2005) \\
\hline
\end{tabular}




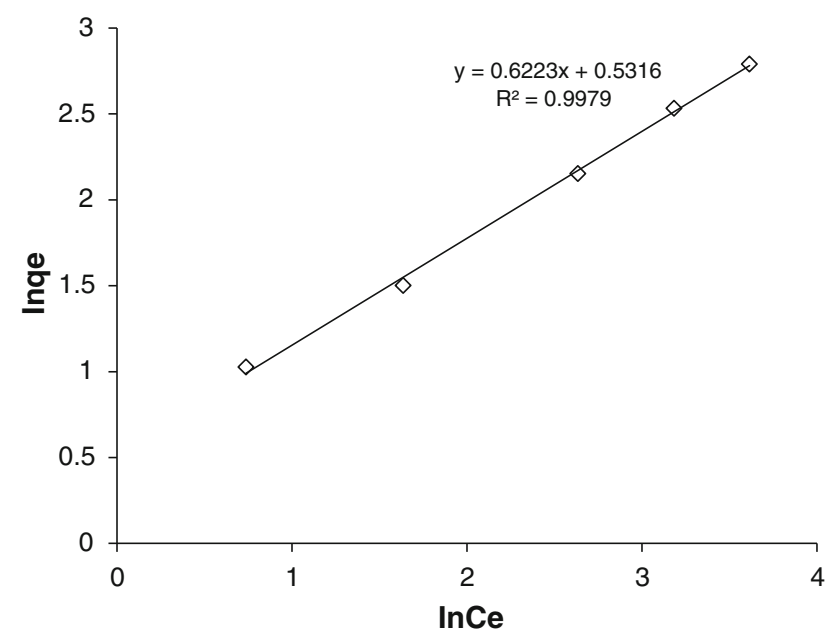

Fig. 5 The linearized Freundlich adsorption isotherms for $\mathrm{Fe}^{3+}$ ions adsorption by $\mathrm{NF}$ (dosage $=10 \mathrm{~g} \mathrm{~L}^{-1}$, Temperature $=30^{\circ} \mathrm{C}$, agitation speed $=300 \mathrm{rpm}$, and contact time $=180 \mathrm{~min}$ )

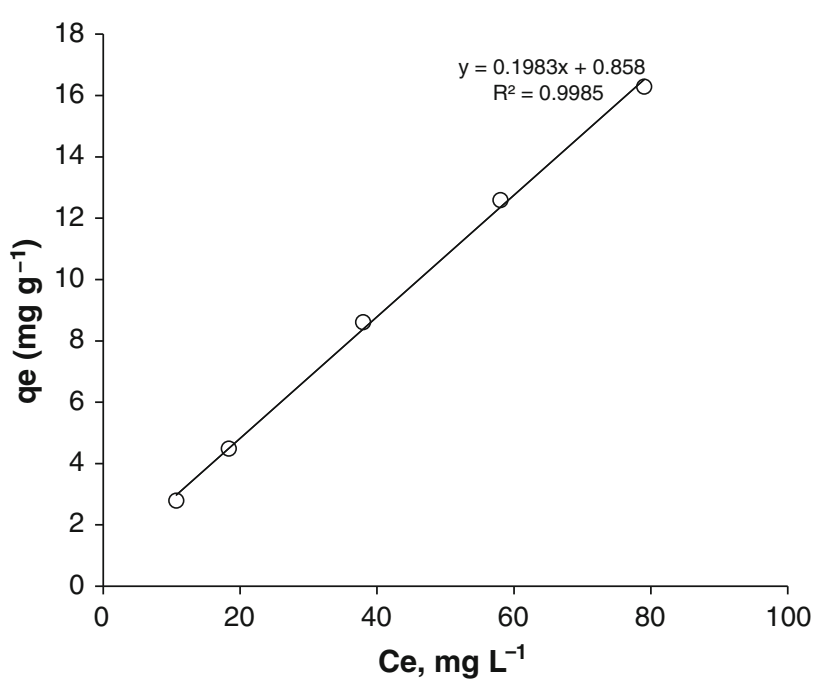

Fig. 6 Experimental isotherms for $\mathrm{Fe}^{3+}$ ions adsorption by $\mathrm{NF}$ $\left(\right.$ dosage $=10 \mathrm{~g} \mathrm{~L}^{-1}$, Temperature $=30^{\circ} \mathrm{C}$, agitation speed $=300 \mathrm{rpm}$ and contact time $=180 \mathrm{~min}$ )

where $C_{i}$ is the initial ferric ion concentration $\mathrm{mg} \mathrm{L}^{-1}$. The calculated $\mathrm{R}_{\mathrm{L}}$ was 0.1785 , indicating for the favorable adsorption.

The apparent Gibbs free energy of sorption $\left(\Delta G^{0}\right)$ is the fundamental criterion of spontaneity. Reaction occurs spontaneously at a given temperature if $\Delta G^{0}$ is negative in value. The standard Gibbs free energy change $\left(\Delta G^{0}\right)$ for the adsorption of $\mathrm{Fe}^{3+}$ ion on the NF surface can be calculated using the following thermodynamic equation

$\Delta G^{0}=-R T \ln K_{\mathrm{L}}$

wherein, $R$ is universal gas constant $\left(8.314 \mathrm{~J} \mathrm{~mol}^{-1} \mathrm{~K}^{-1}\right)$ and $T$ is the absolute temperature in Kelvin and $b$ is the equilibrium constant, related to the Langmuir constant, $b$ (=0.046).

$K_{\mathrm{L}}=b \bullet M_{\mathrm{A}}$

where $M_{\mathrm{A}}$ is the molar weight of sorbate, where $K_{\mathrm{L}}=2,568.87 \mathrm{~L} \mathrm{~mol}^{-1}$.

The value of standard Gibbs free energy change calculated at $30{ }^{\circ} \mathrm{C}$ is found to be $-19.778 \mathrm{~kJ} \mathrm{~mol}^{-1}$. The negative sign for $\Delta G^{0}$ indicates to the spontaneous nature of $\mathrm{Fe}^{3+}$ adsorption on the NF surface.

To justify the validity of NF as an adsorbent for the removal of $\mathrm{Fe}^{3+}$ ions from the aqueous solution, the adsorption potentials, as shown in Table 2, have compared with the adsorbents such as natural bentonite (NB), natural quartz (NQ), olive cake (OC), natural zeolite (NZ) activated carbon, eggshell, chitosan and chitin. Apparently, the maximum sorption of $\mathrm{Fe}^{3+}$ ions onto $\mathrm{NF}$ is greater than chitin, carbon, NZ, NQ and NB.

Kinetic modeling

The kinetics sorption describes the removal rate of $\mathrm{Fe}^{3+}$ ion from the $100 \mathrm{mg} \mathrm{L}^{-1}$ of aqueous solution. Evidently, this rate controls the residence time of $\mathrm{Fe}^{3+}$ ions at the NF solid-liquid interface. The kinetic sorption was analyzed using two kinetic models including the pseudofirst order and pseudo-second order.

\section{Effect of contact time}

The kinetics sorption of $\mathrm{Fe}^{3+}$ ion governs the rate using batch sorption systems. It determines the residence time and defining the efficiency of an adsorbent. Consequently, it is important to establish the time dependency of such systems for various pollutant removal processes. Therefore, the required contact time for sorption to be completed is important to give insight into a sorption process. This also provides information on the minimum time required for considerable adsorption to take place. In addition, it provides the possible diffusion control mechanism between the $\mathrm{Fe}^{3+}$ ions as it moves from the bulk solution toward the NF surface.

The role of contact time was studied under the shaking conditions, for instance, the $\mathrm{pH}$ of solution was 1.15 by using $1 \% \mathrm{HNO}_{3}, 300 \mathrm{rpm}, 10 \mathrm{~g} \mathrm{~L}^{-1}$ dosage of $\mathrm{NF}, 30{ }^{\circ} \mathrm{C}$ and $100 \mathrm{mg} \mathrm{L}^{-1}$ initial $\mathrm{Fe}^{3+}$ ions concentration. Samples were collected at regular intervals and then analyzed after filtration.

The effect of contact time is shown in Fig. 7. At the initial stage, the removal rate of $\mathrm{Fe}^{3+}$ ion is higher with uncontrolled rate. The initial faster rate may be due to the availability of the uncovered surface area of the NF. This is because the adsorption kinetics depends on: (1) the surface 


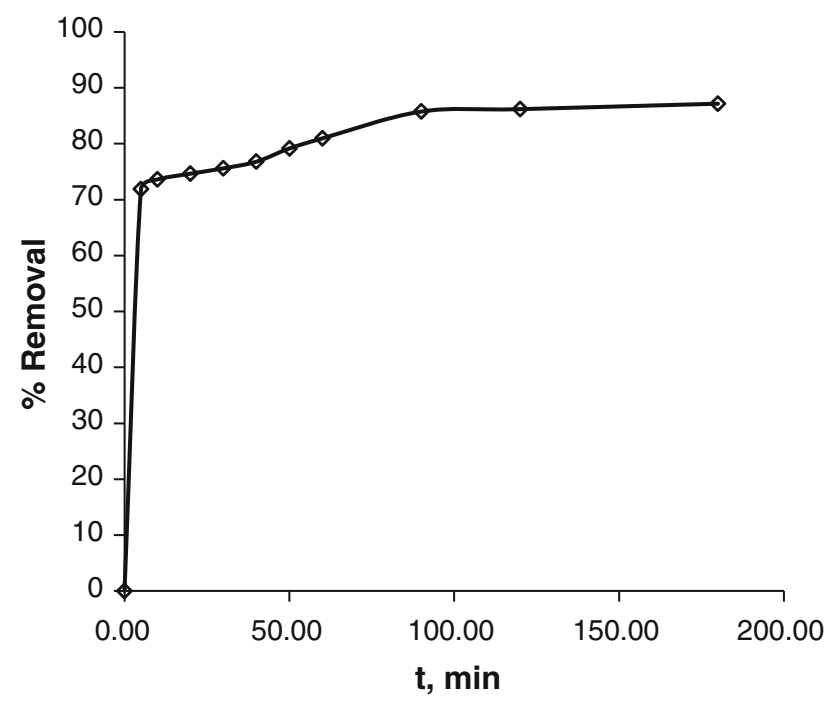

Fig. 7 The effect of contact time on the removal of $100 \mathrm{mg} \mathrm{L}^{-1}$ $\mathrm{Fe}^{3+}$ ions in the interval of 5-120 min (with increment of $10 \mathrm{~min}$ from 10 to $60 \mathrm{~min}$ and then using $30 \mathrm{~min}$ from 60 to $180 \mathrm{~min}$ ), dosage $=10 \mathrm{~g} \mathrm{~L}^{-1}, \quad$ Temperature $=30{ }^{\circ} \mathrm{C}$ and agitation speed (300 rpm)

area of the NF and (2) the nature and concentration of the surface groups (active sites), which are responsible for interaction with the $\mathrm{Fe}^{3+}$ ions. Therefore, the adsorption mechanism on NF adsorbent has uncontrolled rate during the first $5 \mathrm{~min}$. The final equilibrium of sorption starts after 90 min yielded a maximum removal of $93 \%$ (approx.). At the later stages, there is slightly increasing removal efficiency within increasing the contact time. This is due to the decreased or lesser number of active sites. Similar results have been reported in the literature for the removal of dyes, organic acids and metal ions by various adsorbents (Kannan and Meenakshisundaram 2002; Kannan and Xavier 2001; Kannan and Kumar 2003).

\section{Kinetic modeling of $\mathrm{Fe}^{3+}$ sorption}

Many attempts have been made to formulate a general expression describing the kinetics sorption on NF surfaces for liquid-solid phase sorption systems. This has led to the existence of a series of kinetic equations that are used to model metal ions transport onto adsorbent surfaces. In order to investigate the mechanism of sorption of $\mathrm{Fe}^{3+}$ ions on NF, the kinetic profiles using pseudo-first order and pseudo-second order are studied.

The pseudo-first-order kinetic model and its integral can be expressed by the following equation (Lagergren 1898; Aksu 2001; Ho and McKay 1999; Zamani et al. 2013):

$\ln \left(q_{\mathrm{e}}-q_{\mathrm{t}}\right)=\ln q_{\mathrm{e}}-k_{1} t$

where $q_{\mathrm{e}}$ and $q_{\mathrm{t}}\left(\mathrm{mg} \mathrm{g}^{-1}\right)$ are the amounts of adsorbed $\mathrm{Fe} 3+$ ions at equilibrium and at time $(t)$, respectively, $k_{1}$ $\left(\mathrm{min}^{-1}\right)$ is pseudo-first-order rate constant, and $t$ (minuets) is contact time. $k_{1}$ can be determined from the slope of the plot of $\ln \left(q_{\mathrm{e}}-q_{\mathrm{t}}\right)$ versus $t$. The values of the model parameters $k_{1}$ and calculated $q_{\mathrm{e}}$ can be determined by plotting $\ln \left(q_{\mathrm{e}-} q_{\mathrm{t}}\right)$ versus $t$ to produce a straight line of slope $k_{1}$ and intercept lnqe. The rate constants of pseudo-first order $\left(k_{1}\right)$ were found $=0.0283 \mathrm{~min}^{-1}$ for $\mathrm{Fe}^{3+}$ ion adsorption onto NF. The compression of qe values from experimental work $\left(q_{\mathrm{e}}, \operatorname{Exp}=0.65 \mathrm{mg} \mathrm{g}^{-1}\right)$ of this study and calculated one $\left(q_{\mathrm{e}}\right.$, Calc $\left.=2.6464 \mathrm{mg} \mathrm{g}^{-1}\right)$ of pseudosecond-order kinetic model (difference large) does not show the availability of this model. Furthermore, the degree of goodness of linear plot of these kinetic models can be judged from the value of the coefficient of determination of the plot, which can also be regarded as a criterion in the determination of the adequacy of kinetic model. The coefficient of determination value $\left(R^{2}\right)$ is $83 \%$. Therefore, the fitting of the experimental data to the pseudo-first order was not so good.

If we look only to both Figs. 1 and 3, we can get details from the curves that the adsorption system depends almost on the feldspar adsorbent capacity much more than ferric ion concentration in solution. Again, if we look carefully to Fig. 2 in terms of proportional increase of $\mathrm{Fe}^{3+}$ adsorption rate with increasing temperature, although modest increase, then it can be said that the adsorption system is a chemisorptions system. Thus, these two conclusions lead us to use pseudo-second-order kinetic model and its integral form. This model is expressed by the following equation (Ho and McKay 1999; Ho 2004):

$\frac{t}{q_{\mathrm{t}}}=\frac{1}{k_{2} q_{\mathrm{e}}^{2}}+\frac{t}{q_{\mathrm{e}}}$

where $k_{2}$ is the equilibrium rate constant of the pseudosecond-order kinetic model $\left(\mathrm{g} \mathrm{mg}^{-1} \mathrm{~min}^{-1}\right)$. The value of $k_{2}\left(=0.0352 \mathrm{~g} \mathrm{mg}^{-1} \mathrm{~min}^{-1}\right)$ can be determined by plotting $t / q_{\mathrm{t}}$ versus $t$ to obtain a straight line of slope $1 / q_{\mathrm{e}}$ and intercept of $1 /\left(k_{2}\right)$ as shown in Fig. 8. From the determination coefficient value $R^{2}=1$ (approx.), the adsorption model of $\mathrm{Fe}^{3+}$ ion transport onto NF surfaces is regarded as pseudo-second order. Furthermore, the compression of $q_{\mathrm{e}}$ values from experimental work $\left(q_{\mathrm{e}}, \operatorname{Exp}=8.85 \mathrm{mg} \mathrm{g}^{-1}\right)$ of this study and calculated one $\left(q_{\mathrm{e}}, \mathrm{Calc}=8.72 \mathrm{mg} \mathrm{g}^{-1}\right)$ of pseudo-second-order kinetic model (difference smaller) also shows the availability of this model.

The kinetics results of this study are compared with others values as listed in Table 3. Apparently, the pseudosecond-order model was found to be rate limiting, wherein the similar results have been observed using activated carbon (Edwin Vasu 2008), chitin (Karthikeyan et al. 2005), chitosan (Burke et al. 2002 and Wan et al. 2005), egg shells (Yeddou and Bensmaili 2007), olive cakes 
Fig. 8 Pseudo-second order of initial $\mathrm{Fe}^{3+}$ concentration on $10 \mathrm{~g} \mathrm{~L}^{-1}$ dosage, $30{ }^{\circ} \mathrm{C}$, $180 \mathrm{~min}$, initial $\mathrm{pH}$ of $1 \%$ $\mathrm{HNO}_{3}, 300 \mathrm{rpm}$ and constant initial concentration (100 $\mathrm{mg} \mathrm{L}^{-1}$ )

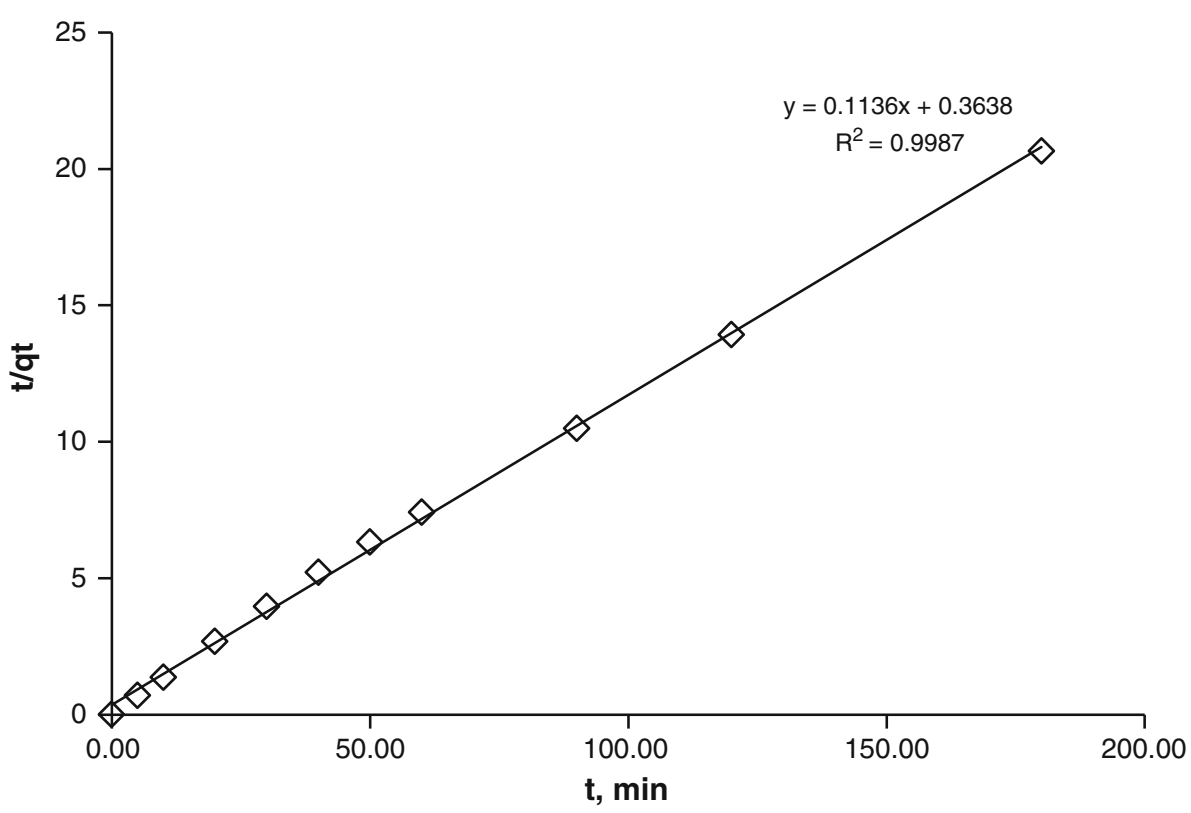

Table 3 List the compression of the parameters of the adsorption kinetic of ferric ion onto various Jordanian natural adsorbents and others

\begin{tabular}{|c|c|c|c|c|c|c|}
\hline & \multicolumn{2}{|c|}{ Pseudo-first order } & \multicolumn{3}{|l|}{ Pseudo-second order } & \multirow[t]{2}{*}{ References } \\
\hline & $k_{1}\left(\min ^{-1}\right)$ & $R^{2}$ & $k_{2}\left(\mathrm{~g} \mathrm{mg}^{-1} \min ^{-1}\right)$ & $q_{\mathrm{e}}$ & $R^{2}$ & \\
\hline \multicolumn{7}{|l|}{ Jordanian adsorbents } \\
\hline Natural bentonite (NB) & 0.066 & 0.89 & 0.337 & 0.649 & 0.99 & (Al-Anber 2010) \\
\hline Natural quartz (NQ) & 0.057 & 0.76 & 0.552 & 0.746 & 0.99 & (Al-Anber 2010) \\
\hline Olive cake (OC) & 0.061 & 0.89 & 0.018 & 15.97 & 0.99 & (Al-Anber and Al-Anber 2008a) \\
\hline Natural zeolite (NZ) & 0.045 & 0.88 & 0.040 & 20.00 & 1.0 & (Al-Anber and Al-Anber 2008b) \\
\hline Feldspar (NF) & 0.378 & 0.83 & 0.035 & 8.85 & 1.0 & This study \\
\hline \multicolumn{7}{|l|}{ Others } \\
\hline Carbon & & & 0.048 & 13.04 & 1.0 & (Edwin 2008) \\
\hline Eggshells & & & 0.403 & 1.92 & 1.0 & (Yeddou and Bensmailiu 2007) \\
\hline Chitosan & 0.0306 & 0.96 & 0.032 & & 1.0 & (Burke et al. 2002 and Wan et al. 2005) \\
\hline
\end{tabular}

(Al-Anber and Al-Anber 2008a), zeolite (Al-Anber and AlAnber 2008b), jojoba seeds (Al-Anber et al. 2011, 2013), natural cotton (Al-Anber 2013), quartz and bentonite (AlAnber 2010).

To determine the diffusibility of the $\mathrm{Fe}^{3+}$ ions into the pores of the adsorbent, Weber-Moris intraparticle diffusion model (Weber and Digiano 1996) was used in the form of the Eq. 12:

$q_{t}=K_{\mathrm{int}} t^{0.5}+c$

where $C$ is constant, $q_{t}$ the amount of metal ions adsorbed at time $\left(\mathrm{mg} \mathrm{g}^{-1}\right)$ and kint is the intraparticle diffusion rate constant $\left(\mathrm{mg} \mathrm{g}^{-1} \mathrm{~min}^{-0.5}\right)$. A plot of $q_{\mathrm{t}}$ versus $t^{0.5}$ giving straight line confirms intraparticle diffusion sorption as shown in Fig. 9. Because the plot is not totally linear and do not pass through the origin, intraparticle diffusion could not be the only mechanism involved. Therefore, it, such plot, presents multi-linearity which indicates that two or more steps occur. The first, sharper portion (ca. $t^{0.5}$ range from 0 to $0.5 \mathrm{~min}^{0.5}$; i.e., from 0 up to $1 \mathrm{~min}$ of adsorption period) is the external surface adsorption or instantaneous adsorption stage. The second portion is the gradual adsorption stage (ca. $t^{0.5}$ range from 0.5 to $0.84 \mathrm{~min}^{0.5}$; i.e., from 1 up to $5 \mathrm{~min}$ of adsorption period), where the intraparticle diffusion is rate controlled $\left(\mathrm{k}_{\mathrm{int}}=5.9296 \mathrm{mg} \mathrm{g}^{-1} \mathrm{~min}^{-0.5}\right.$ and $R^{2}=0.9993$, see Fig. 9). The third portion is final equilibrium stage where the intraparticle diffusion starts to slow down due to extremely low solute concentrations in the solution and chemisorptions stage is taken part on the NF surface and pores (which already has been successfully explained by pseudosecond-order kinetic model from 5 to $120 \mathrm{~min}$ of adsorption period). 
Fig. 9 Weber-Moris intraparticle diffusion kinetic model for adsorption of iron ion on NF starting from 0 to 120 min equilibrium contact time

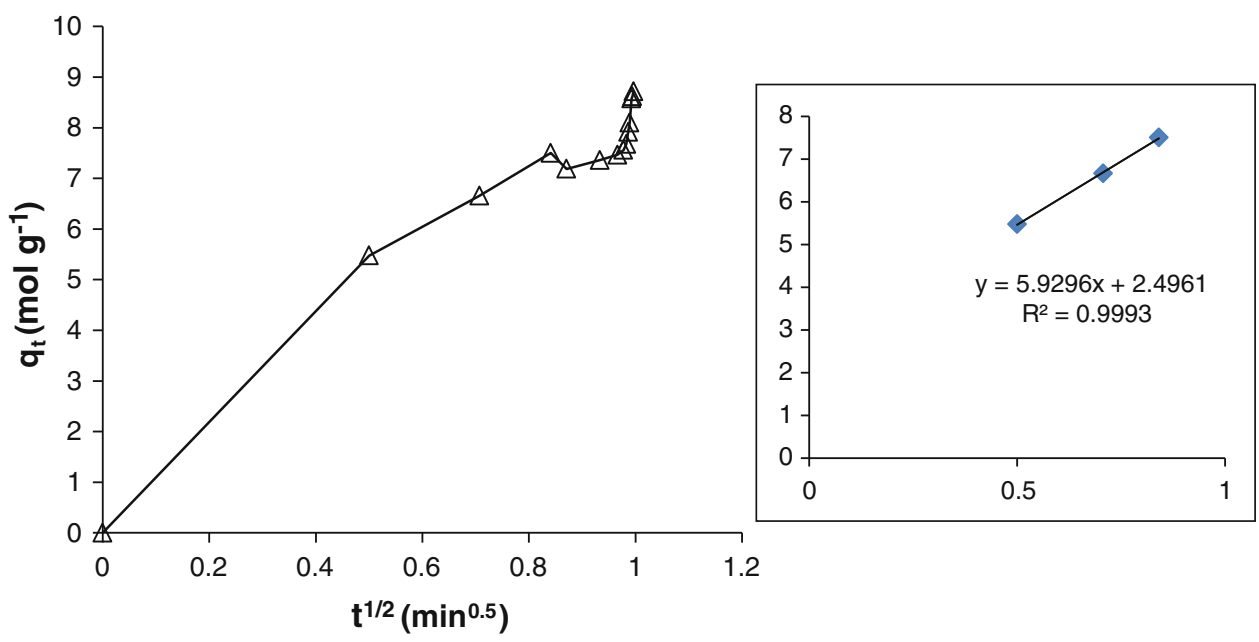

Film diffusion mass transfer rate is presented by Eq. 13: (Boyd et al. 1947).

$\ln \left\{1-\frac{q t}{q e}\right\}=-k t$

where $k\left(\mathrm{~min}^{-1}\right)$ is liquid film diffusion constant. A plot of $\ln \left\{1-\frac{q t}{q e}\right\}$ versus $t$ should be a straight line with a slope $-k$ if the film diffusion is the rate-limiting step. It is found that the plot is nonlinear. Therefore, film diffusion mass transfer stage can be considered as rate-limiting step at the first period of adsorption (0-1 min) where $k=$ 7,215 $\mathrm{min}^{-1}$ and $R^{2}=0.9564$.

Finally, we can describe the adsorption mechanism of ferric ion on natural feldspar through three steps: (1) the external surface adsorption or instantaneous adsorption stage within $0-1 \mathrm{~min}$ of adsorption period, (2) the intraparticle diffusion stage within 1 up to $5 \mathrm{~min}$ of adsorption period and (3) chemisorptions stage and final equilibrium stage within 5-120 min of adsorption period.

\section{Conclusion}

Natural feldspar has been found to be effective for the filtrate of $\mathrm{Fe}^{3+}$ ions from aqueous solution. The maximum removal has been found by applying the following parameters: low-level initial concentration of $\mathrm{Fe}^{3+}$ ions $\left(30 \mathrm{mg} \mathrm{L}^{-1}\right)$ on $40 \mathrm{~g} \mathrm{~L}^{-1}$ NF dosage, Temperature $=30{ }^{\circ} \mathrm{C}$, contact time $=180 \mathrm{~min}$ and $300 \mathrm{rpm}$. The final equilibrium of sorption starts after 90 min yielded a maximum removal of $93 \%$ (approx.). The maximum heterogeneity adsorption capacities represent the fitting data into the Freundlich model spontaneously with $R^{2}=0.997$. The capacity $\left(\mathrm{K}_{\mathrm{f}}\right)$ and intensity $(1 / n)$ of Freundlich adsorption are 1.70 and 0.621 , respectively. The results reveal that the adsorption of ferric ion on NF is chemisorptions, spontaneous $\left(\Delta \mathrm{G}=-19.778 \mathrm{~kJ} \mathrm{~mol}^{-1}\right)$ and favorable in nature $\left(R_{\mathrm{L}}=0.1785\right)$. The kinetics of transporting of $\mathrm{Fe}^{3+}$ ions sorption into NF surfaces in aqueous-solid phase systems are good modeled by pseudo-second order. The chemisorptions of $\mathrm{Fe}^{3+}$ ions on natural feldspar is considered to be the rate-limiting step $\left(R^{2}=1\right)$. The kinetic studies show that the adsorption rate is high. This approach can be applied and recommended for purifying ground water resources and industrial wastewater in Jordan by using a novel feldspar material as natural membrane.

Acknowledgments MA would like to thank Mutah University (Jordan) and University of Hail (Saudi Arabia) for the supporting to do this research.

\section{References}

Aşçı Y, Nurbaş M, SaǵAçıkel Y (2008) A competitive study for the sorption of Cd(II) by K-feldspar and sepiolite as soil component, and the recovery of $\mathrm{Cd}(\mathrm{II})$ using rhamnolipidbiosurfactant. J. Environ. Mang. 88:383-392

Aksu Z (2001) Equilibrium and kinetic modeling of Cadmium(II) biosorption by C. vulgaris in batch system: effect of temperature. Sep Purif Technol 21:285-294

Al-Anber M (2010) Removal of high-level $\mathrm{Fe}^{3+}$ from aqueous solution using natural inorganic materials: bentonite and quartz. Desalination 250:885-891

Al-Anber M (2011) Thermodynamics approach in the adsorption of heavy metals, Chap 27 Juan Carlos Moreno-Pirajan, Thermodynamics-interaction studies-solids, liquids and gases book: 1st edn, InTech, Book : pp 737-764. ISBN: 978-953-307-318-7

Al-Anber MA (2013) Adsorption properties of aqueous ferric ion on the natural cotton fiber: kinetic and thermodynamic studies. Desalination Water Treat 1-12, published on line 07 May 2013, doi:10.1080/19443994.2013.795875

Al-Anber Z, Al-Anber M (2008a) Adsorption of ferric ions from aqueous solution by olive cake: thermodynamic and kinetic studies. J Mex Chem Soc 52:108-115

Al-Anber M, Al-Anber Z (2008b) Utilization of natural zeolite as ionexchange and sorbent material in the removal of iron. Desalination 225:70-81 
Al-Anber Z, Al-Anber M, Matouq M, Al-Ayed O (2011) Defatted jojoba for the removal of methylene blue from aqueous solution: thermodynamic and kinetic studies. Desalination 276:169-174

Al-Anber MA, Al-Anber ZA, Al-Momani I, Al-Momani F, AbuSalem Q (2013) The performance of defatted jojoba seeds for the removal of toxic high-concentration of the aqueous ferric ion. Desalination Water Treatment, doi:10.1080/19443994.2013. 784878

AL-Ghezawi N, Al-Anber MA, Al-Anber ZA, El-Hasan T, AlMomani I (2010) Decontamination and adsorption modeling of aqueous $\mathrm{Pb}^{2+}$ and $\mathrm{Co}^{2+}$ ions using natural inorganic materials: tripoli (NT) and bentonite (NB). Desalination Water Treat 24:336-343

Apodaca LE (2008) Feldspar and nephelinesyenitesyenite. Minerals Yearbook, Feldspar [Advance release]

Appegate LE (1984) Membrane separation processes. Chem Eng 91:64

Awan A, Qai IA, Khalid I (2003) Removal of heavy metals through adsorption using sand. J Environ Sci 15:413-416

Bernardo E, Doyle J, Hampshire S (2008) Sintered feldspar glassceramics and glass-ceramic matrix composites. Ceram Intern 34:2037-2042

Bhattacharyya KG, Gupta SS (2006) Pb(II) uptake by kaolinite and montmorillonite in aqueous medium:influence of acid activation of the clays. Colloids and Surfaces A: Physicochem. Eng Asp 277:191-200

Boyd GE, Adamson AW, Myers LS (1947) The exchange adsorption of ion from aqueous solution by organic zeolites, II, kinetics. J Am Chem Soc 69(11):2836-2848

Brezonik PL (1974) Analysis and speciation of the trace metals in water supply, aqueous environmental chemistry of the metals. In: Rubin AJ (ed) Ann Arbor Science Publishers, Ann Arbor, p $167-191$

Burke A, Yilmaz E, Hasirci N, Yilmaz O (2002) Iron(III) ion removal from solution through adsorption on chitosan. J Appl Polym Sci 84:1185-1192

Disediakan Oleh, Ariffin KS (2003) Feldspathic Minerals Feldspar. EBS 425/3-Mineral Perindustrian, 6:1-16

Domenico PA, Schwartz FW (1990) Physical and chemical hydrogeology, 1st edn. Wiley, New York, pp 1-494

Donald LS (1998). Kinetics of sorption/release reactions on natural particles. Environmental soil chemistry [M]. Academic Press, San Diego pp 1-352

Edwin Vasu A (2008) Adsorption of $\mathrm{Ni}(\mathrm{II}), \mathrm{Cu}(\mathrm{II})$ and $\mathrm{Fe}(\mathrm{III})$ from aqueous solution using activated carbon. Eur J Chem 5:1-9

Fraga CG (2005) Essential and toxicity elements in human health. Molecular aspect of medicine 26:235-244

Geselbarcht J (1996) Micro Filtration/Reverse Osmosis Pilot Trials for Livermore, California, Advanced Water Reclamation. Water Reuse Conference Proceedings AWWA, p 187

Ho YS (2004) Kinetic modeling and equilibrium studies during cadmium biosorption by dead Sargassumsp biomass by Cruz CCV, da Costa, ACA Henriques CA, Luna AS (2004) Biores. Technol 93(3):321-324

Ho YS, McKay G (1999) Pseudo-second order model for sorption processes. Process Biochem 34(5):451-465

Kannan N, Kumar RA (2003) Suitability of various indigenously prepared activated carbons for the adsorption of mercury(II) ions. Toxicol Environ Chem 84(14):7-19

Kannan N, Meenakshisundaram M (2002) Adsorption of Congo red on various activated carbons. a comparative study. Water Air Soil Poll 138:289-305

Kannan N, Xavier A (2001) Studies on the removal of formic acid by flyash-wood carbon blend. Toxicol Environ Chem $19: 859-863$
Karthikeyan G, Andal NM, Anbalagan K (2005) Adsorption studies of iron(III) on chitin. J Chem Sci 117(6):663-672

Kinniburgh DG (1985) Isotherm. A computer program for analyzing adsorption data. Report WD/ST/85/02. Version 2.2. British Geological Survey, Wallingford. England, pp 65-92

Kinniburgh DG (1986) General purpose adsorption isotherms. Environ Sci Technol 20:895-904

Lagergren S (1898) Zurtheorie der sogenannten adsorption gelösterstoffe. Kungliga. SvenskaVetenskapsakademiens. Handlingar 24(4):1-39

Lakshminarayanan Rao KC, Krishniah K, Ashutosh A (1994) Color removal from dye stuff industry effluent using activated carbon. Indian J Chem Technol 1:13-19

Liu YH, Wan XB, Li AH, Dong YY (2007) Bentonite modified and its purification of $\mathrm{Zn}^{2+}$ in water. Chem Bioeng 24:34-35

Michael R, Mark VD, Sandefur KD, Durham KA (2006) Paint. KirkOthmer Encyclopedia of Chemical Technology, 5th edn. 18: $54-76$

Mouflih M, Aklil A, Jahroud N, Gourai M, Sebti S (2006) Removal of lead from aqueous solution by natural phosphate. Hydrometallurgy 81:219-225

Murray BM (1994) Environmental chemistry of soils [M]. Oxford University press, USA, USA, pp 1-416

Nassar MM, Ewida KT, Ebrahiem EE, Magdy YH, Mheaedi MH (2004) Adsorption of iron and manganese ions using low-cost materials as adsorbents. Adsorpt Sci Technol 22:25-37

Natural Resources Authority, Jordan, Report on Feldspar (2006) http://www.nra.gov.jo/images/stories/pdf_files/ Feldspar

Naushad Mu, AL-Othman ZA, Islam M (2013) Adsorption of cadmium ion using a new composite cation-exchanger polyaniline $\mathrm{Sn}(\mathrm{IV})$ silicate: kinetics, thermodynamic and isotherm studies. Int J Environ Sci Technol 10:567-578

Nitzsche O, Vereecken H (2002) Modelling sorption and exchange processes in column experiments and large scale field studies. Mine Water Environ 21:15-23

Pan JF, Lu J (2008) Experimental study on adsorbing the $\mathrm{Pb}^{2+}, \mathrm{Ni}^{2+}$, $\mathrm{Cd}^{2+}$ from wastewater with natural Ca-bentonite and modified Ca-bentonite. China Min Mag 9:35-138

Reddi LN, Inyang HI (2000) Geo-environmental engineering principles and applications, Marcel Decker Inc., New York, p 492

Sengupta AK, Clifford D (1986) Important process variables in chromate ion exchange. Environ Sci Technol 20:149

Siddique BA, Sharma PP, Mohamad S (1999) Adsorption studies on phosphate treated sawdust: separation of $\mathrm{Cr}(\mathrm{VI})$ from $\mathrm{Zn}(\mathrm{II})$, $\mathrm{Ni}(\mathrm{II}), \mathrm{Cu}(\mathrm{II})$ and their removal and recovery from electroplating waste. Ind J Environ Prot 19(11):846-852

Tinschert J, Zwez D, Marx R, Anusavice KJ (2000) Structural reliability of alumina-, feldspar-, leucite-, mica- and zirconiabased ceramics. J Dent 28:529-535

Wan WS, Ghani SA, Kamari A (2005) Adsorption behavior of Fe(II) and $\mathrm{Fe}(\mathrm{III})$ ions in aqueous solution on chitosan and cross-linked chitosan beads. Bioresour Technol 96:443-450

Wang ZA, Zhu YM, Wei DZ, Dai SJ (2006) Research on Adsorption of $\mathrm{Zn}^{2+}$ from Wastewater by Ca-Bentonite. Non-ferr Min Metall 22:45-47

Weber JWJ, Digiano FO (1996) Process dynamics in environmental system; environmental science and technology series. New York, Wiley, pp 89-94

Wikipedia, http://en.wikipedia.org/wiki/Feldspar

Yeddou N, Bensmaili A (2007) Equilibrium and kinetic of iron adsorption by eggshells in a batch system: effect of temperature. Desalination 206:127-134

Yu B, Zhang Y, Shukla A, Shukla SS, Dorris KL (2000) The removal heavy metal from aqueous solution by sawdust adsorptionremoval of copper. J Hazard Mater B80:33-42 
Zamani A, Shokri R, Yaftian M, Parizanganeh A (2013) Adsorption of lead, zinc and cadmium ions from contaminated water onto Peganum harmala seeds as biosorbent. Int J Environ Sci Technol 10:93-102
Zamzow MJ, Murphy JE (1992) Removal of metal cations from water using zeolite. Sep Sci Technol 14:1969

Zeldowitsch J (1934) Über den Mechanismus der katalytischen Oxydation von $\mathrm{CO}$ an $\mathrm{MnO}_{2}$. Acta Physicochim URSS 1:364-449 